\title{
Comparative Analysis of VVER-1000 Westinghouse and TVEL Spent Fuel Capability
}

\author{
Y. Kovbasenko \\ State Scientific and Technical Centre for Nuclear and Radiation Safety (SSTC NRS), Ukraine
}

Copyright $\mathrm{C} 2016$ by authors, all rights reserved. Authors agree that this article remains permanently open access under the terms of the Creative Commons Attribution License 4.0 International License

\begin{abstract}
This work has analyzed the impact on VVER-1000 spent fuel isotope composition caused by the different operational conditions, such as the presence or absence of absorber-rods, oscillating the concentration of boric acid, dissolved in the moderator (water) during the campaign, fuel and/or moderator temperature. Also, impact caused by technological allowances applied while manufacturing fuel assembly was analyzed by weight of fuel and by its enrichment. Calculations were made for reactor cells of fuel assemblies for VVER-1000. They were composed of the typical fuel assemblies of Russian TVEL suppliers and the new fuel assemblies of Westinghouse Company.
\end{abstract}

Keywords Spent Nuclear Fuel, Operational Conditions, Isotopic Composition, Residual Heat

\section{Introduction}

Now for the first time not only in Ukraine, but also for the whole community of Operators of VVER reactors, several Ukrainian units complete the preparations for trial operation of mixed downloads involving fuel of alternative (in relation to the Russian) manufacturer. As such alternative the fuel of Westinghouse Company plan to use. This paper compares the typical fuel assemblies of Russian TVEL suppliers and the new fuel assemblies of Westinghouse Company from the point of view of management and storage of spent fuel.

Spent fuel characteristics important to safety are determined primarily by isotopic composition formed during burnup of this fuel. Determination of isotopic composition of spent fuel is required to solve the tasks related to:

- Account and control of quantity of nuclear hazardous material;

- Determination of source terms during analysis of thermal and radiation safety;

- Using burnup as a nuclear safety parameter while substantiating nuclear safety of spent fuel management systems ("burnup credit" principle).

Isotopic composition of spent fuel is determined by not only its burnup level, but also by those conditions, or to say more exactly, by that neutron spectrum, under which this burnup occurred. Spent nuclear fuel with the same burnup value can have different isotopic composition depending on neutron spectrum in which this burnup took place. The more hard was neutron spectrum, the more U-238 is involved into the burnup process (mainly, due to generation of $\mathrm{Pu}-239$ ), and the more U-235 is remained in spent fuel under the same burnup level. Therefore, this work considers those operational parameters, which changes are capable of influencing upon in-core neutron spectrum hardening.

Impact on VVER-1000 spent fuel isotopic composition caused by different operational conditions, such as the presence or absence of absorber rod - control rod cluster (CR) in guide tubes, oscillating the concentration of boric acid dissolved in the moderator (water) during the campaign, water density, fuel and/or moderator temperature has analyzed. Moreover, the impact caused by manufacturing tolerance applied while manufacturing fuel assembly was analyzed by weight of fuel and by its enrichment, Table 1 .

Table 1. Operational parameters that were used while performing isotope composition calculation

\begin{tabular}{|c|c|c|c|}
\hline Set of parameters & Av. & Max. & Min. \\
\hline Enrichment $(\mathrm{wt} \%)$ & Av & +0.5 & -0.5 \\
\hline Weight $(\mathrm{kg} / \mathrm{FA})$ & Av. & $+4.5 /+5.0$ & $-4.5 /-5.0$ \\
\hline CR in guide tubes & - & + & - \\
\hline Boric acid concentration $(\mathrm{ppm})$ & 525 & 1050 & 0 \\
\hline Water density $(\mathrm{g} / \mathrm{cm} 3)$ & 0.72 & 0.70 & 0.74 \\
\hline Water temp. $(\operatorname{grad} \mathrm{K})$ & 578 & 600 & 500 \\
\hline Fuel temp. $(\operatorname{grad} \mathrm{K})$ & 1005 & 1100 & 900 \\
\hline
\end{tabular}

\section{Code and Model}

US SCALE code package was selected to determine the isotopic composition of spent VVER-1000 fuel assemblies.

The SCALE code package includes computer modules, which combining programs and libraries to calculate one or another problem (criticality analysis, radiation safety, heat transfer, isotopic composition distribution depending on burnup).

The most complete description of the programs included 
in the SCALE is provided in [1].

The applicability of SCALE code package and its libraries of neutron-physical constants for modeling VVER fuel management systems are considered in [2]. To calculate the isotopic composition of spent fuel depending on its burnup, we used the TRITON module of SCALE, which allow to model fuel burnup processes in complex 3D geometry. The calculations were performed using standard 44GROUPNDF5 library of neutron-physical constants.

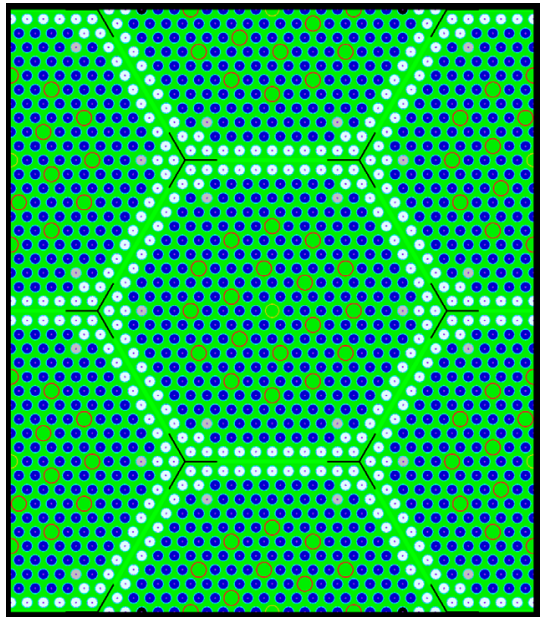

Figure 1. TVS-A model

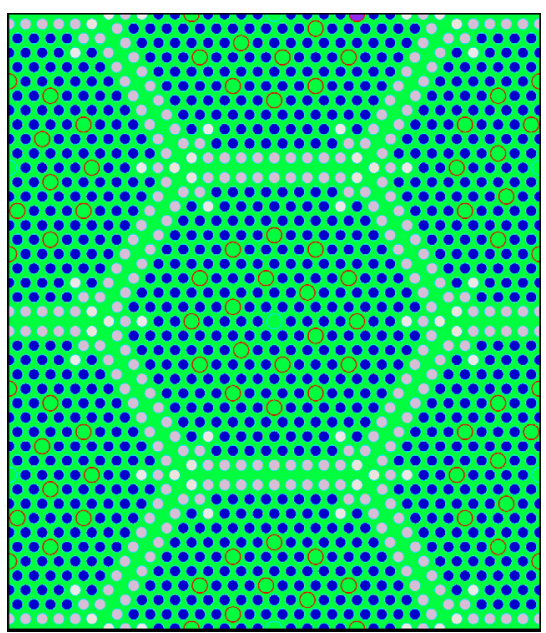

Figure 2. FA-WR model

Calculations were performed for reactor cells of VVER-1000 fuel assemblies under the burnup level up to 50 $\mathrm{GW}^{*}$ day/tU in 4 year fuel cycle. These cells were composed of typical modern fuel assemblies TVS-A of Russian TVEL suppliers (Figure 1) and new fuel assemblies FA-WR of Westinghouse company (Figure 2).

The main differences in geometrical and material parameters of TVS-A and FA-WR used in the calculations are presented in Table 2.

Table 2. The main differences in geometrical and material parameters of TVS-A and FA-WR

\begin{tabular}{|c|c|c|}
\hline Parameter & TVS-A (TVEL) & FA-WR (Westinghouse) \\
\hline Fuel stack length $(\mathrm{mm})$ & 3530 & 3530 \\
\hline Central Zone length (nom.) (mm) & 3530 & 3225.2 \\
\hline Axial Blanket length (nom.) & - & 2 zone x $152.4 \mathrm{~mm}$ \\
\hline Fuel mass (UO2) (kg) & $494.5(4.5$ & $550.6 \pm 5.0$ \\
\hline \multicolumn{3}{|c|}{ Fuel pin (312 pieces/FA) } \\
\hline Enrichment (wt\%) & $\begin{array}{c}306 * 4.4 \%+ \\
6 * 3.6 \%(\mathrm{BA})\end{array}$ & $\begin{array}{c}240 * 4.2 \%+ \\
60 * 3.9 \%+ \\
6 * 3.6 \%+ \\
6 * 3.0 \%(\mathrm{BA}) \\
0.714 \% \text { (blanket) } \\
\end{array}$ \\
\hline Pellet ID/OD (mm) & $1.4 / 7.57$ & $-/ 7.84$ \\
\hline Cladding ID/OD $(\mathrm{mm})$ & 7.73/9.1 & $8.0 / 9.14$ \\
\hline Cladding material/ density $(\mathrm{g} / \mathrm{cm} 3)$ & alloy Э110 / 6.45 & alloy ZIRLOTM / 6.55 \\
\hline \multicolumn{3}{|c|}{ Central tube } \\
\hline $\mathrm{ID} / \mathrm{OD}, \mathrm{mm}$ & $11.0 / 13.0$ & $11.0 / 12.6$ \\
\hline Material / density (g/cm3) & alloy Э635 / 6.45 & alloy ZIRLOTM / 6.55 \\
\hline \multicolumn{3}{|c|}{ Guide tube (18 pieces) } \\
\hline $\mathrm{ID} / \mathrm{OD}(\mathrm{mm})$ & $10.9 / 12.6$ & $11.0 / 12.6$ \\
\hline Material & alloy Э635 & alloy ZIRLOTM \\
\hline \multicolumn{3}{|c|}{ Spacer grid (13 pieces in fuel zone/FA) } \\
\hline Mass $(\mathrm{g})$ & 550 & 830 \\
\hline Material / density $(\mathrm{g} / \mathrm{cm} 3)$ & alloy Э110 / 6.45 & alloy $718 / 8.18$ \\
\hline \multicolumn{3}{|c|}{ Ribs (6 stiffener corners/FA) } \\
\hline Width / thickness (mm) & $52 / 0.65$ & - \\
\hline Material & alloy Э635 & - \\
\hline
\end{tabular}




\section{Results of Calculations}

Multiplying properties of assemblies depending on burnup for average operational parameters (column Av., Table 1) are shown in Figure 3. Despite of larger fuel amount (550.6 vs. $494.5 \mathrm{~kg}$ ) Westinghouse FA-WR has lower multiplying properties comparative to TVS-A of TVEL Company. Obviously, this is due to lower average fuel enrichment of FA-WR.

Parameters playing an important part in assessing nuclear and radiation safety in spent fuel management and storage, such as activity, residual heat release, as well as concentration of a number of $\mathrm{U}, \mathrm{Pu}, \mathrm{Cs}$ and $\mathrm{Eu}$ isotopes were selected for analysis.

Sets of initial data were formed for each selected parameter according to the results of preliminary sensitivity analysis. They include fuel assembly characteristics (fuel enrichment and fuel weight) and operational data (fuel temperature, presence or absence of control rods in guide tubes, boric acid concentration in water coolant, water density and temperature), which allow obtaining the maximum (column Max., Table 1) and the minimum (column Min., Table 1) value of considered parameter regarding the average value (column Av., Table 1).

Then, calculations were performed for each set of the initial data (Av., Max., Min., see Table 1). Results of these calculations are presented in Figure 4-12 and Table 3.

Table 3. Parameters variations for TVS-A and FA WR

\begin{tabular}{|c|c|c|c|c|c|}
\hline \multirow{2}{*}{$\begin{array}{c}\text { Set of } \\
\text { parameters }\end{array}$} & \multicolumn{2}{|c|}{ TVS-A } & \multicolumn{2}{c|}{ FA-WR } & \multirow{2}{*}{ FA-WR vs } \\
\cline { 2 - 5 } & Av. & $\begin{array}{c}\text { Max./ } \\
\text { Min. }\end{array}$ & $\begin{array}{c}\text { Max./ } \\
\text { Av. }\end{array}$ & $\begin{array}{c}\text { Max./ } \\
\text { Min. }\end{array}$ & TVS-A \\
\hline Residual heat & 1.23 & 1.31 & 1.22 & 1.30 & 1.22 \\
\hline $\begin{array}{c}\text { U235 } \\
\text { concentration }\end{array}$ & 1.32 & 1.46 & 1.34 & 1.48 & 0.89 \\
\hline $\begin{array}{c}\text { U236 } \\
\text { concentration }\end{array}$ & 1.05 & 1.08 & 1.05 & 1.07 & 0.98 \\
\hline $\begin{array}{c}\text { Pu239 } \\
\text { concentration }\end{array}$ & 1.45 & 1.59 & 1.44 & 1.57 & 1.25 \\
\hline $\begin{array}{c}\text { Pu } \\
\text { concentration }\end{array}$ & 1.31 & 1.39 & 1.30 & 1.38 & 1.24 \\
\hline $\begin{array}{c}\text { Activity } \\
\text { Eu154 } \\
\text { concentration }\end{array}$ & 1.10 & 1.13 & 1.10 & 1.13 & 1.14 \\
\hline $\begin{array}{c}\text { Cs134 } \\
\text { concentration }\end{array}$ & 1.18 & 1.24 & 1.17 & 1.22 & 1.33 \\
\hline $\begin{array}{c}\text { Cs } \\
\text { concentration }\end{array}$ & 1.06 & 1.08 & 1.06 & 1.08 & 1.11 \\
\hline
\end{tabular}

Figure 5 - 8 present concentrations of the main fuel isotopes, such as U-235, U-236, Pu-239, as well as total concentration of $\mathrm{Pu}$ isotopes, which are important in assessing nuclear safety in spent fuel management and storage.
The following parameters were selected to analyze radiation safety: activity of spent fuel, residual heat release, as well as isotope concentrations contributing significantly spent fuel activity, for example, Cs-134, Eu-154, as well as total concentration of Cs isotopes, Figure 4 and Figure 9 - 12.

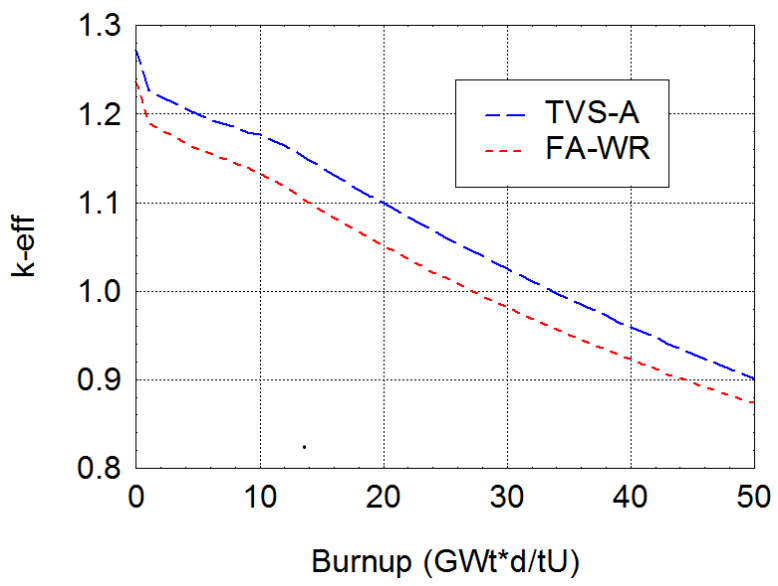

Figure 3. Effective multiplication factor vs burnup

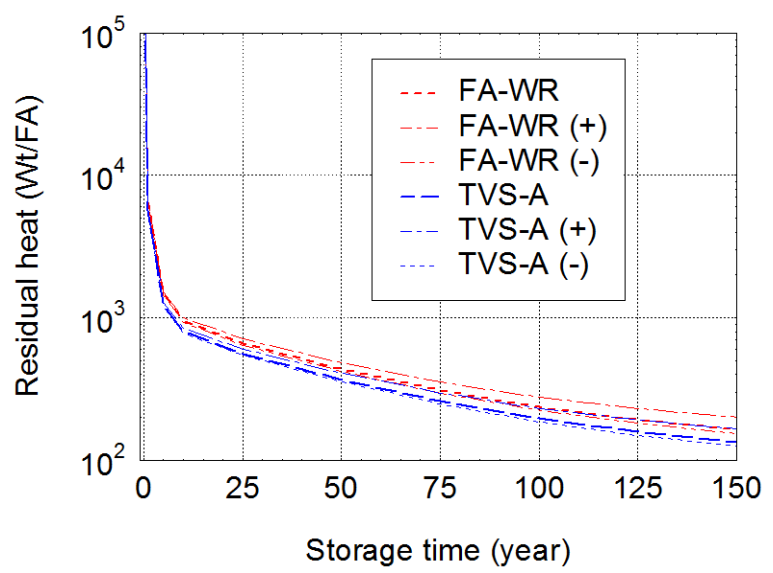

Figure 4. Spent fuel assembly residual heat release in dependence from cooling time

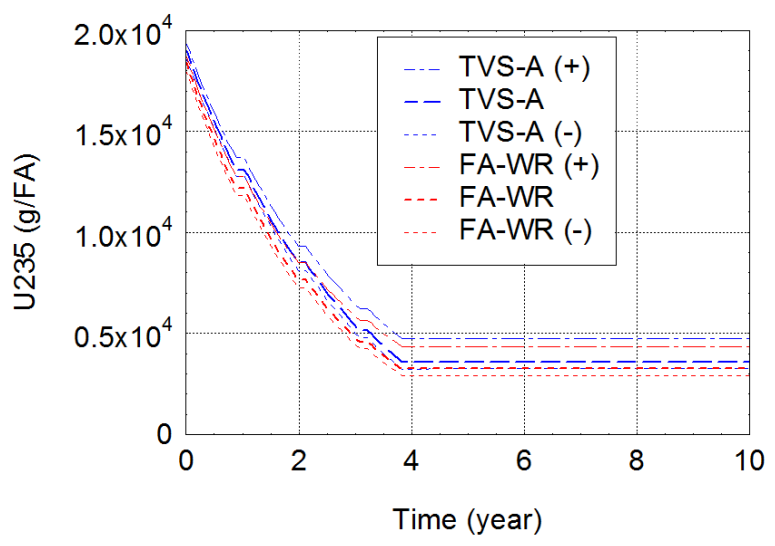

Figure 5. Mass of U235 isotope in operation and storage 


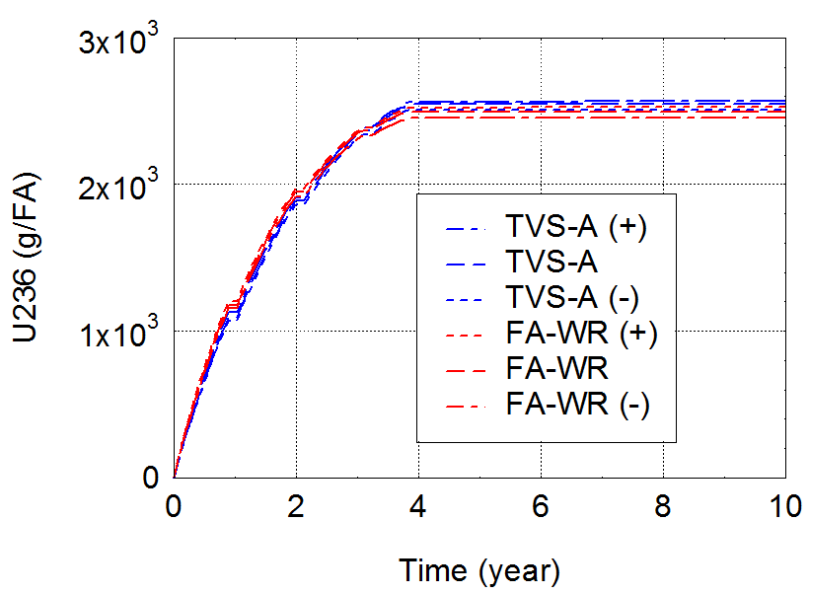

Figure 6. Mass of U236 isotope in operation and storage

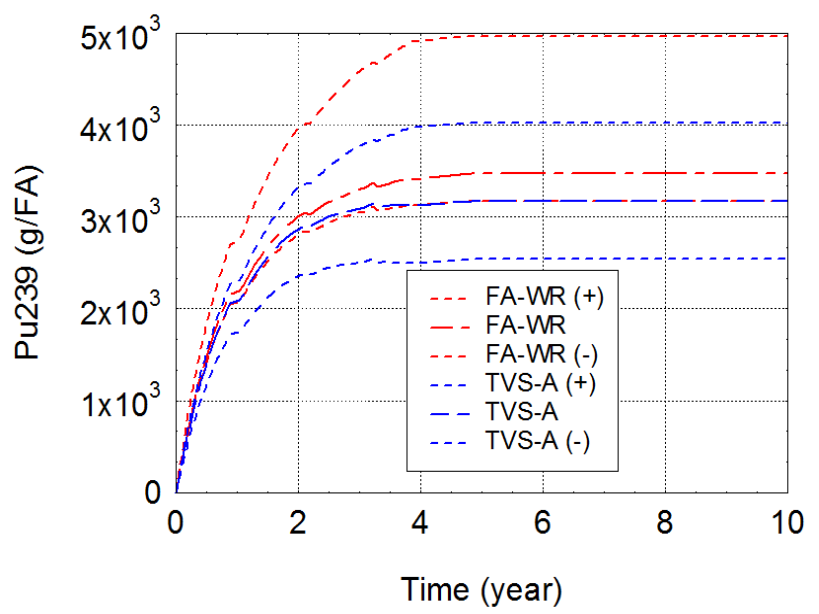

Figure 7. Mass of Pu239 isotope in operation and storage

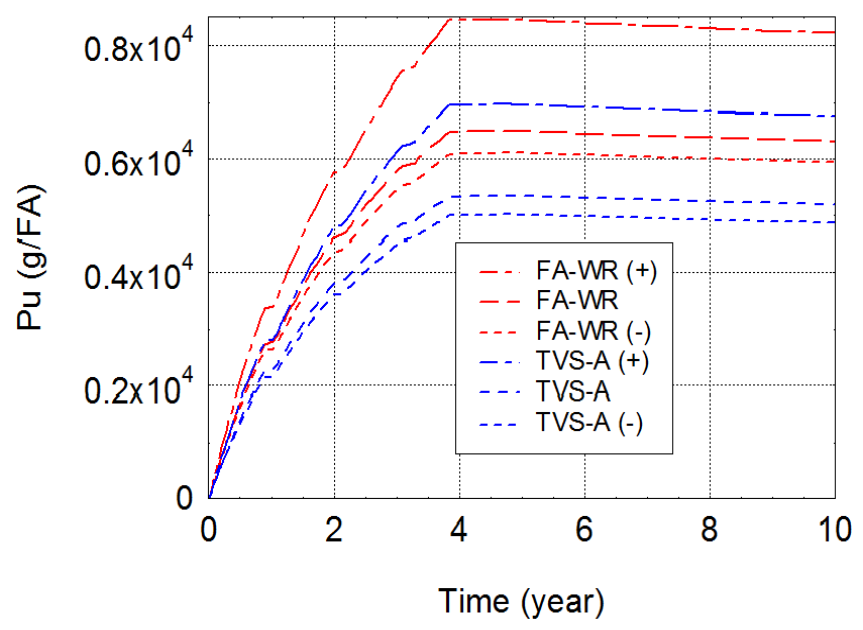

Figure 8. Total mass of Pu-isotopes in operation and storage

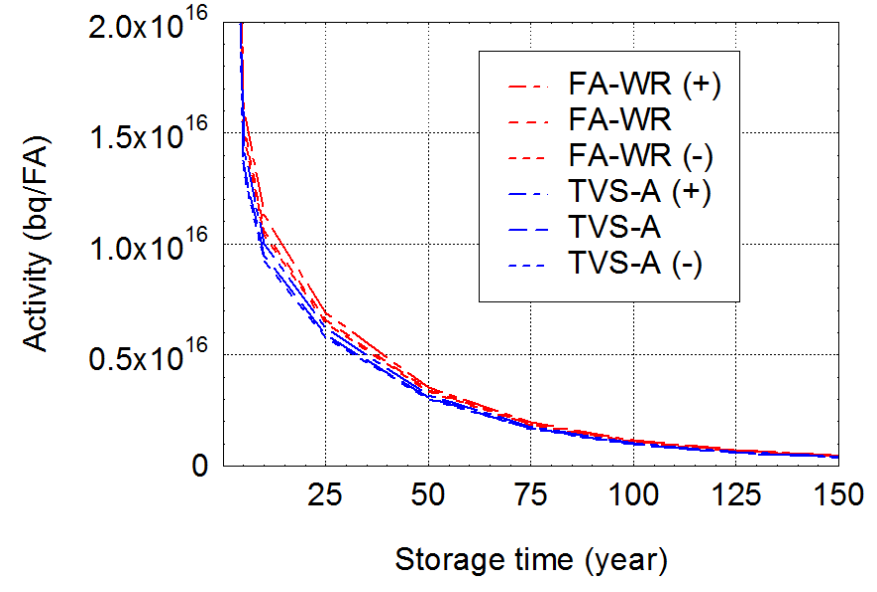

Figure 9. Spent fuel assembly activity in dependence from cooling time

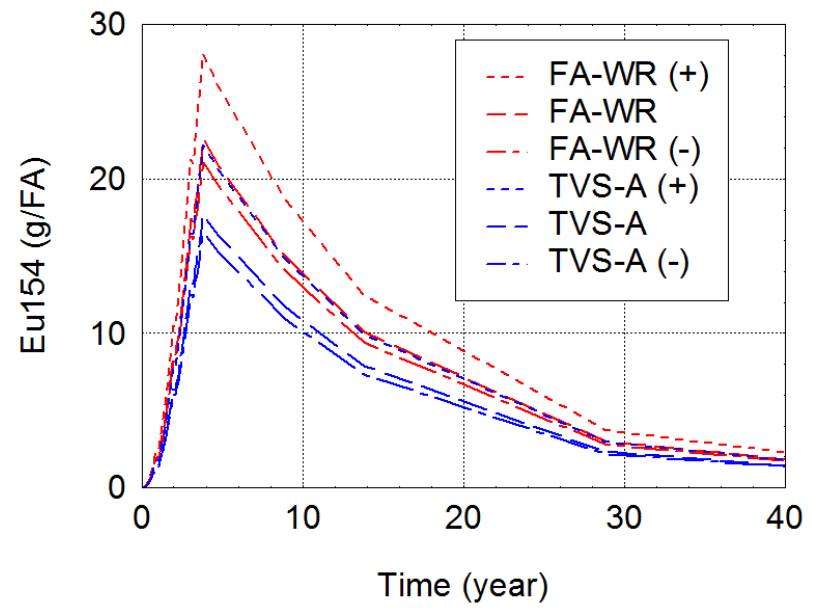

Figure 10. Mass of Eu154 isotope in operation and storage

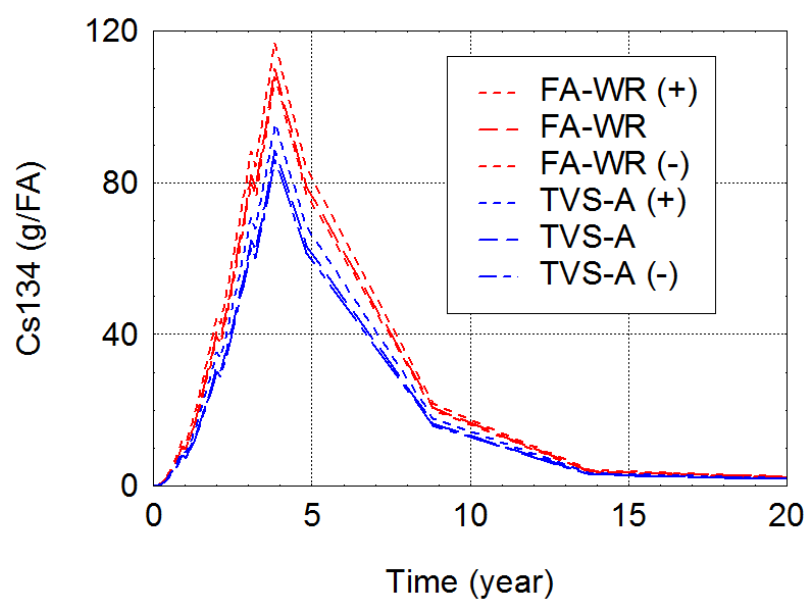

Figure 11. Mass of Cs134 isotope in operation and storage 


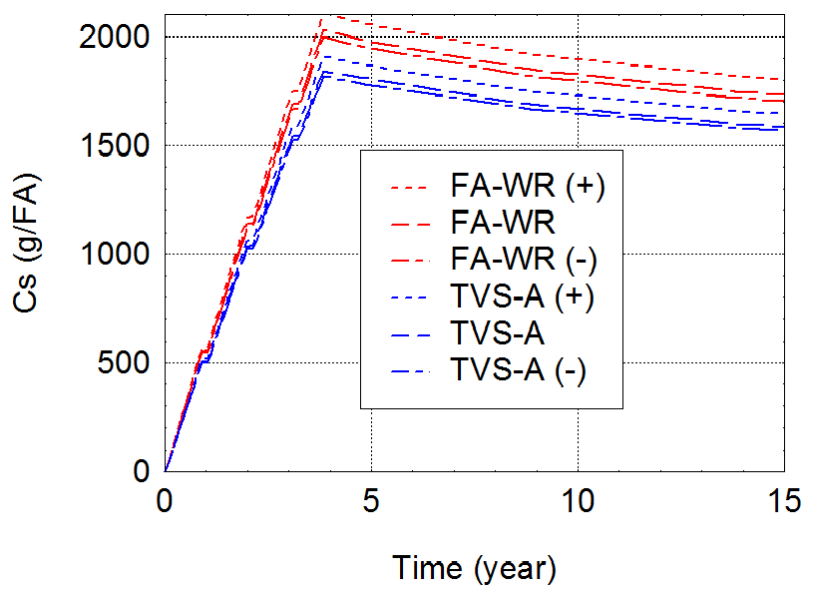

Figure 12. The total mass of Cs-isotopes in operation and storage

\section{Analysis and Conclusions}

First of all, we note that at the same burnup spent FA-WR (Westinghouse) have lower multiplying properties relative to the TVS-A (TVEL). This means that there are additional safety margins in normal and emergency operating conditions or the possibility of additional loading spent fuel management systems

In general the conducted studies demonstrated that VVER-1000 spent assemblies TVS-A (TVEL) and FA-WR (Westinghouse) at the burnup level of $50 \mathrm{GWtd} / \mathrm{t}$ have the following ranges of possible parameters fluctuations relative to its value for average and Min. operational conditions (Max./Av. and Max./Min.), presented in Table3.

Only for three characteristics "Activity", "U236 concentration" and "Cs concentration" the calculated changes depend on manufactory tolerances and operational conditions are negligible (less than 10\%).

Other characteristic varies within the limits from 20 to $50 \%$. Especially strong dependence within $50 \%$ both TVS-A and FA-WR are observed for Pu-239 concentration.
For the remaining considered characteristics it is significantly lower and does not exceed $40 \%$. The main differences are observed after termination of fuel assembly operation in the reactor, during the first years of storage in spent fuel pool.

As regards all considered spent fuel characteristics obtained values determined for average rated operational parameters are not average values and are closer to the minimum possible values. Such results are connected with the possibility of presence control rods clasters within assembly, which has the significant influence on spent fuel isotope composition.

It is necessary to note slightly more extensive heat release in FA-WR (Westinghouse) compared to TVS-A (TVEL) under the same burnup depth. This can cause the need for slightly longer post-operation fuel cooling in spent fuel pool.

In general, obtained results allow making conclusion that from the viewpoint of safe spent fuel management and storage implementing new alternative fuel of Westinghouse company at VVER-1000 does not require modifications of current conditions and procedures. For the majority of considered spent fuel characteristics the differences between TVS-A (TVEL) and FA-WR (Westinghouse) are less than total changes of these characteristics depending on production tolerance and operation conditions.

\section{REFERENCES}

[1] SCALE User's Manual. NUREG/CR-0200 Revision 6. RNL/NUREG/CSD-2/V2/R6.

[2] Y. Kovbasenko, V. Khalimonchuk, A. Kuchin, Y. Bilodid, M. Yeremenko, O. Dudka, NUREG/CR-6736, PNNL-13694 "Validation of SCALE Sequence CSAS26 for Criticality Safety Analysis of VVER and RBMK Fuel Designs", Washington, U.S. NRC, 2002. 